\title{
The influence of incubation on the formation of volatile bacterial metabolites in mastitis milk
}

\author{
K. A. Hettinga, ${ }^{* 1}$ H. J. F. van Valenberg, ${ }^{*}$ T. J. G. M. Lam,† and A. C. M. van Hooijdonk* \\ *Dairy Science and Technology group, Wageningen University and Research Centre, 6700EV Wageningen, the Netherlands \\ †GD Animal Health Service Ltd., 7420AA Deventer, the Netherlands
}

\begin{abstract}
The possibility to detect mastitis-causing pathogens based on their volatile metabolites was previously studied. In that study, the mastitis samples were incubated overnight. To minimize the total analysis time, no incubation, or a short incubation, would be preferred. We therefore investigated the effect of the incubation time on the formation of volatile metabolites in mastitis samples. A selection of 6 volatile metabolites with the highest impact on the prediction model for identifying the mastitis-causing pathogen, was compared at different incubation times between 0 and $24 \mathrm{~h}$. Identification of the pathogens was not possible without incubation. The minimum incubation time for detection of most of the 6 metabolites was 4 to $8 \mathrm{~h}$. Although a longer incubation time increased the differences between pathogens, after $8 \mathrm{~h}$ all metabolites could be detected and the pathogens could be differentiated. Eight hours was therefore selected as the optimal incubation time. This optimal incubation time was evaluated with a set of 25 mastitis samples, of which $88 \%$ were correctly classified after $8 \mathrm{~h}$ of incubation. The total analysis time for this method is therefore considerably shorter than current microbiological culturing.
\end{abstract}

Key words: mastitis, metabolite, pathogen, artificial neural network

\section{INTRODUCTION}

Although many bacteria can cause mastitis, a limited group of 5 bacteria (Staphylococcus aureus, CNS, Streptococcus uberis, Streptococcus dysgalactiae, and Escherichia coli) is responsible for approximately $80 \%$ of the Dutch mastitis cases from which bacteria can be cultured (Barkema et al., 1998; Sampimon et al., 2008). Determination of mastitis-causing pathogens is of great interest, for choice of treatment as well as for

Received October 20, 2008.

Accepted June 24, 2009.

${ }^{1}$ Correponding author: kasper.hettinga@wur.nl herd-level management measures to prevent the spread of mastitis.

Previous research (Hettinga et al., 2008a) showed that analysis of volatile metabolites could be used for mastitis pathogen identification. Diagnosis based on the analysis of volatile metabolites in milk samples was comparable with bacteriological culturing. For that study, the samples were incubated overnight at $37^{\circ} \mathrm{C}$. After incubation, the volatile metabolites were identified and quantified using GC-MS. Subsequently, a probabilistic neural network (PNN) was used to identify the mastitis-causing pathogens based on the pattern of volatile metabolites.

The selected incubation time before GC-MS analysis will influence both the result of the analyses as well as the total analysis time. A relatively long incubation time will increase the quantity of volatile metabolites formed by the bacteria, which may increase the differences in patterns of metabolites between bacteria. These increased differences may be beneficial for discrimination between pathogens. On the other hand, the incubation time should be as short as possible to minimize the total analysis time.

The formation and possible subsequent breakdown of metabolites will be a function of time and will depend upon the type of bacteria. Breakdown products of the bacterial metabolism (primary metabolites) can occur even in an early phase of growth, especially if extracellular enzymes are involved. For example, Staph. aureus is known to produce extracellular lipase as soon as it starts growing (Smeltzer et al., 1992). This lipase will hydrolyze triglycerides to FFA. Free fatty acids may thus be detected without incubation or after only a short incubation time.

Secondary metabolites, such as branched FFA, were detected after incubation of Staph. aureus (Ritter and Hanni, 1960; Zechman et al., 1986). The production of branched aldehydes by Staphylococcus species has been shown to occur in the exponential growth phase (de Vos Petersen et al., 2004). Depending on a possible lag time before the pathogen starts to grow, these branched aldehydes may thus be detected after even a short incubation. Branched aldehydes can subsequently be 
enzymatically converted to branched FFA or branched alcohols (Masson et al., 1999; de Vos Petersen et al., 2004). Thus, longer incubation times are needed before these conversion products of the branched aldehydes can be detected. After very long incubation times, this process will also cause the concentration of branched aldehydes to decrease (de Vos Petersen et al., 2004).

Finally, some components are associated with cell lysis and will therefore only be found after long incubation times when high bacterial numbers are reached. An example of such a component is acetoin, which is produced by Staph. aureus (Yang et al., 2006).

The aim of this study was to evaluate the effect of incubation time on the formation of volatile metabolites in mastitis milk samples, to be able to select the optimal incubation time for mastitis pathogen identification.

\section{MATERIALS AND METHODS}

\section{Mastitis Milk Samples}

Milk samples were collected from quarters of cows with clinical mastitis on 4 dairy herds in the area of Wageningen, the Netherlands. From each affected quarter, two 10-mL samples were taken. The first sample was used for bacteriological culturing according to NMC protocols (NMC, 2004). The second sample was stored at $-45^{\circ} \mathrm{C}$. If 1 of the 5 pathogens of interest (Staph. aureus, CNS, Strep. uberis, Strep. dysgalactiae, or E. coli) was cultured, the second sample was selected for the experiments described below. Twenty-five samples were selected, 5 samples per pathogen. Only samples from which 1 bacterial species was cultured were used. The samples were used for either selecting the optimal incubation time or for evaluating the selected incubation time. For selecting the optimal incubation time, 2 samples per pathogen were used. For evaluating the optimal incubation time, 3 additional samples per pathogen were used. The mastitis milk samples described in our previous publication (Hettinga et al., 2008a) were used as comparison for the GC-MS results of the samples from the incubation test.

\section{Incubation Test}

For the 5 pathogens of interest, 2 samples per pathogen were divided into nine $1-\mathrm{mL}$ samples. These samples were put in $20-\mathrm{mL}$ sterilized headspace vials sealed with silicon/Teflon septa and magnetic caps (for analysis of volatile metabolites) or in 10-mL sterile tubes (for microbiological counting). For analysis of volatile metabolites, 6 samples were incubated at $37^{\circ} \mathrm{C}$ for $0,2,4,8,14$, and $24 \mathrm{~h}$. After incubation, these samples were frozen at $-20^{\circ} \mathrm{C}$ for later analysis of the volatile metabolites. For microbiological counting, 3 samples were incubated at $37^{\circ} \mathrm{C}$ for 0,8 , and $24 \mathrm{~h}$. Microbiological counting was done immediately after incubation, using plate counting. For counting the number of Staph. aureus and CNS in the milk samples, mannitol salt agar (CM0085, Oxoid, Cambridge, UK) was used. For counting the number of Strep. uberis and Strep. dysgalactiae, BHI agar (CM0375, Oxoid) was used. For counting the number of $E$. coli, selective $E$. coli medium (CM1046, Oxoid) was used.

\section{Evaluation Test}

After selecting the optimal incubation time based on the incubation test, 3 additional samples per pathogen were incubated at $37^{\circ} \mathrm{C}$ for evaluation of this selected incubation time. After incubation, these samples were frozen at $-20^{\circ} \mathrm{C}$ for later analysis of the volatile metabolites.

\section{Analysis of Volatile Metabolites}

The volatiles were analyzed using solid-phase microextraction combined with GC-MS according to Hettinga et al. (2008a).

\section{Statistics}

SPSS for Windows, version 12.0 (SPSS Inc., Chicago, IL) was used for statistical analysis of bacterial numbers. Analysis of variance was used for comparison of bacterial numbers between pathogens after 0,8 , and $24 \mathrm{~h}$ with a Welch test in case of unequal variances. A $P$-value $<0.05$ was considered statistically significant.

NeuralTools (Palisade, Ithaca, NY) was used to predict the pathogen in the samples based on the previously developed PNN (Hettinga et al., 2008a). After the incubation test, data from the 10 samples were individually used for predicting the mastitis-causing pathogen. After the evaluation test, 5 samples per pathogen were used: 2 samples from the incubation test which had been incubated to choose the optimal incubation time and 3 samples from the evaluation test.

\section{RESULTS}

\section{Microbiological Counting}

The number of pathogens in the nonincubated mastitis samples were all below the detection limit $(<5$ $\times 10^{3} \mathrm{cfu} / \mathrm{mL}$ ). After $8 \mathrm{~h}$, all samples contained approximately $10^{7} \mathrm{cfu} / \mathrm{mL}$. After $24 \mathrm{~h}$, the number of pathogens had risen to around $10^{8} \mathrm{cfu} / \mathrm{mL}$. Analysis of variance revealed no significant differences in the num- 
Table 1. Amount (arbitrary unit of area) of volatile metabolites found after different incubation times

\begin{tabular}{|c|c|c|c|c|c|c|}
\hline Incubation time & Ethanol & 2-Methylbutanal & Acetoin & Butyric acid & $\begin{array}{l}\text { 3-Methyl- } \\
\text { butyrate }\end{array}$ & $\begin{array}{c}\text { Ethyl } \\
\text { hexanoate }\end{array}$ \\
\hline \multicolumn{7}{|c|}{ Staphylococcus aureus } \\
\hline $0 \mathrm{~h}$ & $\mathrm{ND}^{1}$ & ND & ND & $9.0 \times 10^{3}$ & ND & ND \\
\hline $4 \mathrm{~h}$ & ND & $3.2 \times 10^{3}$ & ND & $2.7 \times 10^{6}$ & ND & ND \\
\hline $8 \mathrm{~h}$ & $2.4 \times 10^{5}$ & $4.7 \times 10^{5}$ & $4.2 \times 10^{4}$ & $2.9 \times 10^{7}$ & $2.1 \times 10^{5}$ & ND \\
\hline $14 \mathrm{~h}$ & $1.4 \times 10^{8}$ & $2.8 \times 10^{6}$ & $1.1 \times 10^{6}$ & $8.5 \times 10^{6}$ & $2.2 \times 10^{6}$ & ND \\
\hline \multicolumn{7}{|l|}{ CNS } \\
\hline $0 \mathrm{~h}$ & ND & ND & ND & ND & ND & ND \\
\hline $2 \mathrm{~h}$ & ND & ND & ND & ND & ND & ND \\
\hline $4 \mathrm{~h}$ & ND & $2.7 \times 10^{3}$ & ND & $8.7 \times 10^{4}$ & ND & ND \\
\hline $8 \mathrm{~h}$ & $5.4 \times 10^{5}$ & $1.5 \times 10^{4}$ & ND & $1.8 \times 10^{5}$ & ND & $1.1 \times 10^{3}$ \\
\hline $14 \mathrm{~h}$ & $1.3 \times 10^{6}$ & $1.6 \times 10^{4}$ & ND & $1.4 \times 10^{5}$ & ND & $2.7 \times 10^{2}$ \\
\hline $24 \mathrm{~h}$ & $1.5 \times 10^{6}$ & $1.8 \times 10^{5}$ & $5.2 \times 10^{4}$ & $1.1 \times 10^{6}$ & ND & $2.2 \times 10^{3}$ \\
\hline $8 \mathrm{~h}$ & $1.1 \times 10^{6}$ & ND & ND & $3.1 \times 10^{6}$ & ND & ND \\
\hline $14 \mathrm{~h}$ & $5.4 \times 10^{6}$ & $7.7 \times 10^{4}$ & ND & $1.4 \times 10^{6}$ & ND & ND \\
\hline $24 \mathrm{~h}$ & $7.7 \times 10^{6}$ & $1.9 \times 10^{5}$ & ND & $6.5 \times 10^{6}$ & ND & ND \\
\hline Reference & $1.6 \times 10^{6}$ & $2.7 \times 10^{3}$ & $3.6 \times 10^{3}$ & $7.8 \times 10^{5}$ & ND & $6.4 \times 10^{4}$ \\
\hline \multicolumn{7}{|c|}{ Streptococcus dysgalactiae } \\
\hline $0 \mathrm{~h}$ & ND & ND & ND & ND & ND & ND \\
\hline $2 \mathrm{~h}$ & ND & ND & ND & ND & ND & ND \\
\hline $4 \mathrm{~h}$ & ND & ND & ND & ND & ND & ND \\
\hline $8 \mathrm{~h}$ & $1.5 \times 10^{5}$ & ND & ND & $1.4 \times 10^{5}$ & ND & $6.0 \times 10^{3}$ \\
\hline $14 \mathrm{~h}$ & $5.5 \times 10^{8}$ & ND & ND & $1.5 \times 10^{6}$ & ND & $1.9 \times 10^{4}$ \\
\hline $24 \mathrm{~h}$ & $5.2 \times 10^{7}$ & ND & $1.4 \times 10^{6}$ & $4.0 \times 10^{6}$ & ND & $6.6 \times 10^{4}$ \\
\hline Reference & $5.8 \times 10^{6}$ & $2.7 \times 10^{3}$ & ND & $1.0 \times 10^{6}$ & $7.2 \times 10^{2}$ & $9.2 \times 10^{4}$ \\
\hline \multicolumn{7}{|l|}{ Escherichia coli } \\
\hline $0 \mathrm{~h}$ & $2.9 \times 10^{6}$ & ND & ND & $3.6 \times 10^{4}$ & ND & ND \\
\hline
\end{tabular}

${ }^{1} \mathrm{ND}=$ not detected.

ber of bacteria between the pathogens after different incubation times.

\section{Analysis of Volatile Metabolites}

Corresponding with earlier observations, only a limited number of components were found in nonincubated mastitis samples (Hettinga et al., 2008b). No differences were observed between nonincubated samples containing different pathogens.

After overnight incubation, 19 volatile metabolites were found in the reference samples as reported previously (Hettinga et al., 2008a). Not all of these 19 metabolites were equally important for the identification of the mastitis-causing pathogens.

The NeuralTools software used for developing the PNN calculated a variable impact analysis, which showed the relative effect of each variable on the model outcome. Based on this impact analysis, a combination of 6 volatile metabolites, ethanol, 2-methylbutanal, 3-hydroxy-2-butanone (acetoin), butyric acid, 3-methylbutyrate, and ethyl hexanoate, was shown to explain approximately $98 \%$ on the model outcome. Thus, for comparing the different incubation times in the incubation test, we focused on these 6 metabolites. Table 1 shows the abundance of the 6 selected volatile metabolites. Only ethanol and butyric acid were found in some of the nonincubated samples.

During incubation, the concentration of most components increased considerably. After $8 \mathrm{~h}$, most components were detectable. After $24 \mathrm{~h}$, the differences between the milk samples were more obvious, and a quick visual examination of the chromatogram was enough to identify the mastitis-causing pathogens. Ethanol 
Table 2. Correct classification rate of the prediction by the previously developed probabilistic neural network (Hettinga et al., 2008a) for the mastitis-causing pathogen in mastitis sample incubated for $0,2,4,8$, 14 , and $24 \mathrm{~h}$

\begin{tabular}{lc}
\hline Incubation time $(\mathrm{h})$ & Correct classification rate $(\%)$ \\
\hline 0 & 40 \\
2 & 40 \\
4 & 50 \\
8 & 90 \\
14 & 90 \\
24 & 60 \\
\hline
\end{tabular}

was formed by all pathogens, although the minimum incubation time before detection was either 0 or $8 \mathrm{~h}$. In samples with Staph. aureus and CNS, 2-methylbutanal was detected after $4 \mathrm{~h}$. For the reference samples, this component was one of the main differences between the staphylococci and other pathogens. In the other incubated samples, it was not formed at all by E. coli and Strep. dysgalactiae and only after $14 \mathrm{~h}$ of incubation by Strep. uberis.

Acetoin and 3-methylbutyrate are components specifically formed by Staph. aureus in the reference samples. In the current study, 3-methylbutyrate was found to be produced only by Staph. aureus, for which it was detected after $8 \mathrm{~h}$ of incubation. Acetoin, on the other hand, was found to be produced by most pathogens, although in samples with Staph. aureus, it could be detected after $8 \mathrm{~h}$ of incubation, whereas it could only be detected in the other samples after an incubation time of $24 \mathrm{~h}$.

Butyric acid could be detected in nonincubated samples with Staph. aureus and E. coli, although only at a relatively low level. After 4 to $8 \mathrm{~h}$ of incubation, butyric acid was detected in all samples in relatively high amounts.

Ethyl hexanoate was formed in considerable amounts only by Strep. dysgalactiae and E. coli. The amount of ethyl hexanoate formed in the incubated samples was in general lower than in the reference samples.

\section{PNN}

The correct classification rate of the PNN after the different incubation times can be found in Table 2. Samples incubated for 8 and $14 \mathrm{~h}$ had the highest correct classification rate $(90 \%)$. The prediction of the PNN for the 25 samples incubated for $8 \mathrm{~h}$ can be found in Table 3, showing a correct classification rate of $88 \%$.

\section{DISCUSSION}

Compared with the other metabolites, acetoin and 3 -methylbutyrate needed a longer incubation time before they could be detected. For acetoin, this was expected, as it is associated with cell lysis (Yang et al., 2006). For 3-methylbutyrate, this can be explained by the fact that it is a conversion product of 3-methylbutanal. First, 3-methylbutanal must be formed before it can be converted to 3-methylbutyrate. The later formation during incubation of 3-methylbutyrate compared with its precursor 3-methylbutanal has also been shown by de Vos Petersen et al. (2004). Because these 2 metabolites are important for the PNN, mainly for identification of Staph. aureus, a relatively longer incubation time may be required.

Although butyric acid could be detected in samples with Staph. aureus and E. coli without incubation, the level of butyric acid in these samples was low, and a similar amount of butyric acid has previously been found in samples of milk from healthy cows (Hettinga et al., 2008b). The amount of butyric acid in these nonincubated samples is therefore too low for mastitis diagnosis.

For identification of the mastitis-causing pathogen using GC-MS, differences in metabolites must be detectable. When looking at the formation of the 6 metabolites, 4 to $8 \mathrm{~h}$ of incubation time was the minimum for detection of most of them. A longer incubation time had the advantage that differences between pathogens were larger.

Table 3. Prediction of the mastitis-causing pathogen in the sample incubated for $8 \mathrm{~h}$ with the previously developed probabilistic neural network (Hettinga et al., 2008a)

\begin{tabular}{lccccc}
\hline & \multicolumn{4}{c}{ Predicted by PNN ${ }^{1}$} \\
\cline { 2 - 5 } Microbiological identification & Staphylococcus aureus & CNS & Streptococcus & Escherichia coli & Correct $(\%)$ \\
\hline Staph. aureus & 5 & 0 & 0 & 0 & 0 \\
CNS & 0 & 4 & 1 & 0 & 1 \\
Streptococcus & 0 & 0 & 1 & 4 & 80 \\
E. coli & 0 & 0 & & 80 \\
Total correct & & & & 88 \\
\hline
\end{tabular}

${ }^{1}$ The number of samples classified in the respective group by the probabilistic neural network (PNN). 
The PNN was used to help select the optimal incubation time. As expected based on the amount of volatile metabolites found, incubation times up to 4 $\mathrm{h}$ are too short for pathogen identification. After $8 \mathrm{~h}$ of incubation, $90 \%$ of the samples were correctly classified. This correct classification rate did not increase after incubating for $14 \mathrm{~h}$. After $24 \mathrm{~h}$ the correct classification rate decreased to $60 \%$. This decrease probably occurs because the neural network was developed for samples that had been incubated overnight (Hettinga et al., 2008a). The pattern of volatile metabolites found after $24 \mathrm{~h}$ of incubation was considerably different from the reference samples (see Table 1). If a PNN were developed for samples incubated for $24 \mathrm{~h}$, a correct classification rate similar to that found for the samples incubated for 8 or $14 \mathrm{~h}$ would be expected. Developing a PNN for samples incubated for $4 \mathrm{~h}$ would probably not increase its correct classification rate, because the pathogens show almost no difference in the pattern of volatile metabolites after this incubation time. Because total analysis time should be as short as possible, and the correct classification rate after $8 \mathrm{~h}$ was comparable to the rate after $14 \mathrm{~h}, 8 \mathrm{~h}$ was considered the optimal incubation time.

The correct classification rate of $88 \%$ as found for the 25 samples used in the evaluation test is similar to the $93 \%$ found for the 50 reference samples (Hettinga et al., 2008a). This confirms that $8 \mathrm{~h}$ of incubation is sufficient for mastitis pathogen identification.

\section{CONCLUSIONS}

Incubation was shown to be a necessary step to identify mastitis-causing pathogens by detection of their volatile metabolites. After $8 \mathrm{~h}$ of incubation, all the important metabolites had been formed. The selected optimal incubation time for this method was thus $8 \mathrm{~h}$. This was evaluated with a set of 25 mastitis samples, of which $88 \%$ were correctly classified after $8 \mathrm{~h}$ of incubation.

\section{REFERENCES}

Barkema, H. W., Y. H. Schukken, T. J. G. M. Lam, M. L. Beiboer, H. Wilmink, G. Benedictus, and A. Brand. 1998. Incidence of clinical mastitis in dairy herds grouped in three categories by bulk milk somatic cell counts. J. Dairy Sci. 81:411-419.

de Vos Petersen, C., H. C. Beck, and F. R. Lauritsen. 2004. On-line monitoring of important organoleptic methyl-branched aldehydes during batch fermentation of starter culture Staphylococcus xylosus reveal new insight into their production in a model fermentation. Biotechnol. Bioeng. 85:298-305.

Hettinga, K. A., H. J. F. van Valenberg, T. J. G. M. Lam, and A. C. M. van Hooijdonk. 2008a. Detection of mastitis pathogens by analysis of volatile bacterial metabolites. J. Dairy Sci. 91:3834-3839.

Hettinga, K. A., H. J. F. van Valenberg, and A. C. M. van Hooijdonk. 2008b. Quality control of raw cows' milk by headspace analysis. Int. Dairy J. 18:506-513.

Masson, F., L. Hinrichsen, R. Talona, and M. C. Montel. 1999. Factors influencing leucine catabolism by a strain of Staphylococcus carnosus. Int. J. Food Microbiol. 49:173-178.

NMC. 2004. Microbiological Procedures for Use in the Diagnostics of Bovine Udder Infection and Determination of Milk Quality. National Mastitis Council, Inc., Madison, WI.

Ritter, W., and H. Hanni. 1960. The application of gas chromatography in dairying. II. Detection and determination of volatile fatty acids in dairy products and cultures. Milchwissenschaft 15:296-302.

Sampimon, O. C., R. G. M. Olde Riekerink, and T. J. G. M. Lam. 2008. Prevalence of subclinical mastitis pathogens and adoption of udder health management practice on Dutch dairy farms: Preliminary results. Pages 39-46 in Proc. Mastitis Control 2008 "From Science to Practice." The Hague, the Netherlands.

Smeltzer, M. S., M. E. Hart, and J. J. Iandolo. 1992. Quantitative spectrophotometric assay for staphylococcal lipase. Appl. Environ. Microbiol. 58:2815-2819.

Yang, S.-J., P. M. Dunman, S. J. Projan, and K. W. Bayles. 2006. Characterization of the Staphylococcus aureus CidR regulon: Elucidation of a novel role for acetoin metabolism in cell death and lysis. Mol. Microbiol. 60:458-468.

Zechman, J. M., S. Aldinger, and J. N. Labows Jr.. 1986. Characterization of pathogenic bacteria by automated headspace concentration-gas chromatography. J. Chromatogr. 377:49-57. 